\title{
The Menace of Nosocomial Infections
}

\author{
Sumit Sharma* and Sueeba Shabir \\ Department of E.N.T., Mayo Institute of Medical Sciences, India
}

Submission: April 26, 2017; Published: May 05, 2017

*Corresponding author: Sumit Sharma, MBBS (ENT-Honors) (KGMC-Lko), M.S. (KGMC-Lko), Assistant Professor, Department of E.N.T., Mayo Institute of Medical Sciences, Barabanki, India, Tel: 98391 78240; Email: entsumit@rediffmail.com

Abbreviations: CDC: Center for Disease Control; UTI: Urinary Tract Infections; MRSA: Methicillin-Resistant S. Aureus; CoNS: CoagulaseNegative Staphylococci

\section{Introduction}

"Nosocomial" term is used for any disease acquired by patient under medical care [1] Health care establishments like hospitals, nursing homes, or outpatient facilities - are dangerous places for the acquisition of these infections. The most common type of nosocomial infections are secondary surgical wound infections, chest infections, genitourinary infections, as well as gastrointestinal tract infections. Often breaches of infection control practices and procedures, unclean and non-sterile environmental surfaces, and/or ill employees are the root cause of these infections. With nearly 100 million procedures performed at hospitals each year the incidence of these infections are increasing all the time. Immune-compromised patients and extremes of age like the elderly and young children are more susceptible than others. These infections are transmitted through direct contact from the hospital staff, inadequately sterilized instruments, aerosol droplets from other ill patients or even the food or water provided at hospitals.

\section{Types of Nosocomial Infections}

National Healthcare Safety Network with Center for Disease Control (CDC) for surveillance has classified nosocomial infection sites into 13 types, with 50 infection sites, which are specific on the basis of biological and clinical criteria. The sites which are common include

a. Hospital-acquired pneumonia including Ventilatorassociated pneumonia,
b. Urinary tract infections (UTI),
c. Surgical and soft tissue infections,
d. Gastroenteritis,
e. Meningitis and

\section{f. Respiratory infections [2] and}

g. Puerperal fever

A change regarding nosocomial infection sites can be easily detected with time due to the elevated use of cancer chemotherapy, advancement in organ transplantation, immunotherapy and invasive techniques for diagnostic and therapeutic purposes. The perfect example of this can be seen in the case of pneumonia as prevalence of nosocomial pneumonia increased from $17 \%$ to $30 \%$ during five years [3].

\section{Agents of Nosocomial Infections}

Nosocomial infections are caused by many microbes and each one can cause infection in healthcare settings. Bacteria are responsible for about ninety percent infections, whereas protozoans, fungi, viruses and mycobacteria are less contributing compared to bacterial infections [4]. The agents that are usually involved in hospital-acquired infections include

a. Staphylococcus aureus'

b. Methicillin resistant Staphylococcus aureus

c. Candida albicans

d. Pseudomonas aeruginosa

e. K. pneumonia

f. Acinetobacter baumannii'

g. Stenotrophomonas maltophilia

h. Clostridium difficile

i. Escherichia coli

j. Tuberculosis 


\section{Global Journal of Otolaryngology}

k. Vancomycin-resistant Enterococcus

l. Legionnaires' disease

UTI usually contain E. coli, while it is uncommon in other infection sites. Contrarily, $S$. aureus is frequent at other body sites and rarely causes UTI. In blood-borne infections, coagulasenegative $S$. aureus is the main causative agent. Surgical-site infections contain Enterococcus spp. which is less prevalent at respiratory tract. One tenth of all infections are caused by $P$. aeruginosa, which is evenly distributed to the entire body sites [4].

Excessive and improper use of broad-spectrum antibiotics, especially in healthcare settings, are elevating nosocomial infections. Penicillin-resistant pneumococci, multi-drugresistant tuberculosis, methicillin-resistant S. aureus (MRSA), vancomycin-resistant $S$. aureus are common examples of drugresistant bacteria. The distribution of bacteria in nosocomial infections is changing over time. For example, Proteus spp., Klebsiella spp. and Escherichia spp. were responsible for nosocomial infections in the 1960s, but from 1975 to 1980 s, Acinetobacter spp. with P. aeruginosa created clinical difficulties [5]. During the recent years, streptococci along with coagulasenegative staphylococci and coagulase-positive staphylococci reemerged and incidence level of $K$. pneumonia and E. coli declined from $7 \%$ to $5 \%$ and $23 \%-16 \%$, respectively [6].

\section{Modes of Transmission}

It has been observed that various organisms take various routes to enter human body in nosocomial infections, like $S$. aureus is transmitted through infected individuals' skin or contact via shared items and surfaces like door handles, benches, towels and taps, while E. coli can be transmitted through person to person, environment or contaminated water and food [7]. Patients suffering from Diarrhea are commonly infected by Vancomycin-resistant enterococci, daily use items like surfaces and equipments act as reservoirs. This bacterium can survive on theses surfaces for days or weeks and become a source of contamination for healthcare individuals and other patients [8].

$K$. pneumonia is usually transmitted through person-toperson contact mainly in those who do not wash hands after examining a contaminated patient. Respiratory machines, catheters or exposed wounds can be the source of its transmission. K. pneumoniae is reported to be transmitted through stool (77\%), patients' hands (42\%) and pharynx (19\%) [9]. For P. aeruginosa Common reservoirs for its contamination include breast pumps, incubators, sinks and hands of hospital staff and hand soaps [10]. C. difficile spores hold for many days and become a problem for disinfectants and cleaning agents, are also important nosocomial infections Inanimate objects and infected intestinal patients are major sites acted as reservoirs. Hospital staff along with hospital settings is also playing their part to a greater extent [11].

\section{Comments}

Laboratories in a hospital play an important role in diagnosing and suggesting treatment of these infections. Success of any organization in controlling these Hospitals acquired infections depend to a large extent on active involvement of the laboratory in all aspects of the infection control program and the Laboratories must coordinate with the hospital's infection control program. The organisms also show a change in the pattern of the infection as well as change in the organism pattern over the years. Compared with the 1970s, the pathogens associated with nosocomial infections changed dramatically during the 1980s. The Nosocomial pathogens are also more difficult to treat with routine antibiotics and also show varying degree of antibiotic resistance. For example, the percentage of infections with P. aeruginosa and Enterobacter spp. increased, while those with E. coli decreased. The reporting of coagulase-negative staphylococci (CoNS) increased dramatically, particularly for blood isolates, from $9 \%$ of all pathogens in 1980 to 31\% during 1990 through 1992. Although the changes probably represent a true increase in infections with this organism, there has been an increased propensity to report CoNS in cultures as true pathogens rather than as contaminants, as in the past.

It's important for all organizations to develop an infection control programs. Guidelines for the sterilization and disinfection of invasive devices and medical instruments used for surgeries were developed as the infection rates tend to raise [12]. Moreover, guidelines for the prevention of catheter-associated UTI were also devised in 2009 [13]. Most of these organizations do not have knowledge of these guidelines and lack of compliance with the guidelines, leads to the transmission of nosocomial infections. The most important part of these infection control programs is the training of healthcare professionals, especially nurses, which is extremely important for the control and prevention of infection [14]. Infection prevention and control guidelines have been developed but the implementation is not yet much known [15]. Besides awareness a large gap exists between the existence of guidelines and their actual implementation [16].

\section{References}

1. S. Krishna Prakash (2014) Nosocomial infection-an overview.

2. L Raka, D Zoutman, G Mulliqi, S Krasniqi, I Dedushaj, et al. (2006) Prevalence of nosocomial infections in high-risk units in the university clinical center of Kosova. Infect Control Hosp Epidemiol 27(4): 421423.

3. AS Duque, AF Ferreira, RC Cezârio, PG Filho (2007) Nosocomial infections in two hospitals in Uberlandia, Brazil. Rev Panam Infectol $9(4): 14-18$.

4. S Gatermann, R Fünfstück, W Handrick, L Leitritz, KG Naber, et al. (2005) MIQ 02: Urinary Tract Infections: Quality standards for microbiological infections. Urban \& Fischer, München, Germany, pp. 8-21.

5. Gordon RJ, Lowy FD (2008) Pathogenesis of methicillin-resistant Staphylococcus aureus infection. Clin Infect Dis 46 (S5): S350-S359. 
6. E Klein, DL Smith, R Laxminarayan (2007) Hospitalizations and deaths caused by methicillin-resistant Staphylococcus aureus, United States, 1999-2005. Emerg Infect Dis 13(12): 1840-1846.

7. Lausch KR, Fuursted K, Larsen CS, Storgaard M (2013) Colonisation with multi-resistant Enterobacteriaceae in hospitalised Danish patients with a history of recent travel: a cross-sectional study. Travel Med Infect Dis 11(5): 320-323.

8. Sood S, Malhotra M, Das BK, Kapil A (2008) Enterococcal infections \& antimicrobial resistance. Indian J Med Res 128(2): 111-121.

9. Lin YT, Wang YP, Wang FD, Fung CP (2015) Community-onset Klebsiella pneumoniae pneumonia in Taiwan: clinical features of the disease and associated microbiological characteristics of isolates from pneumonia and nasopharynx. Front Microbiol 9: 122.

10. Rabier V, Bataillon S, Jolivet-Gougeon A, Chapplain JM, Beuchée A, et al.(2008) Hand washing soap as a source of neonatal Serratia marcescens outbreak. Acta Paediatr 97(10): 1381-1385.

11. SL Gu, YB Chen, T Lv, XW Zhang, ZQ Wei, et al. (2015) Risk factors, outcomes and epidemiology associated with Clostridium difficile infection in patients with haematological malignancies in a tertiary care hospital in China. J Med Microbiol 64 (Pt 3): 209-216.

12. Rutala WA, Weber DJ, Society for Healthcare Epidemiology of America (2010) Guideline for disinfection and sterilization of prioncontaminated medical instruments. Infect Control Hosp Epidemiol 31(2): 107-117.

13. Gould CV, Umscheid CA, Agarwal RK, Kuntz G, Pegues DA, et al. (2010) Guideline for prevention of catheter-associated urinary tract infections 2009. Infect Control Hosp Epidemiol 31(4): 319-326.

14. Pegram A, Bloomfield J (2015) Infection prevention and control. Nurs Stand 29(29): 37-42.

15. Stone PW, Herzig CT, Pogorzelska-Maziarz M, Carter E, Bjarnadottir RI, et al. (2015) Understanding infection prevention and control in nursing homes: a qualitative study. Geriatr Nurs 36(4): 267-272.

16. MG Menegueti, SR da Silva Canini, F Bellissimo-Rodrigues, AM Laus (2015) Evaluation of nosocomial infection control programs in health services. Rev Lat Am Enferm 23(1): 98-105.

\section{Your next submission with Juniper Publishers} will reach you the below assets

- Quality Editorial service

- Swift Peer Review

- Reprints availability

- E-prints Service

- Manuscript Podcast for convenient understanding

- Global attainment for your research

- Manuscript accessibility in different formats

( Pdf, E-pub, Full Text, Audio)

- Unceasing customer service

Track the below URL for one-step submission https://juniperpublishers.com/online-submission.php 